\title{
Characterization of a broad-host-range flagellum- dependent phage that mediates high-efficiency generalized transduction in, and between, Serratia and Pantoea
}

Correspondence

G. P. C. Salmond

gpcs@mole.bio.cam.ac.uk

Received 10 August 2009

Revised 19 September 2009

Accepted 21 September 2009

\author{
T. J. Evans, ${ }^{1}$ M. A. Crow, ${ }^{1}$ N. R. Williamson, ${ }^{1}$ W. Orme, ${ }^{1}$ N. R. Thomson, ${ }^{1} \dagger$ \\ E. Komitopoulou ${ }^{2}$ and G. P. C. Salmond ${ }^{1}$ \\ ${ }^{1}$ Department of Biochemistry, University of Cambridge, Cambridge CB2 1OW, UK \\ ${ }^{2}$ Leatherhead Food International Limited, Randalls Road, Leatherhead KT22 7RY, UK
}

\section{INTRODUCTION}

Bacteriophages are obligate intracellular parasites. However, the choice of host is usually considered to be specific. Generally, phages have been found to infect a single bacterial strain only, or related strains from the same species, in laboratory screens. There are several reasons for this. First, an appropriate receptor, which can be recognized by the corresponding phage-borne anti-receptor, must be expressed on the bacterial surface; the antireceptor may be tail fibres or the base plate in the case of tailed phages. Next, the viral DNA must be injected into the host without significant host-controlled restriction. Finally, viral replication and virion assembly must occur before cell lysis; these steps can be actively targeted by abortive infection systems encoded by the bacterium. Some phages are so specific for subspecies and serotypes that phage sensitivity can be used to differentiate between closely related strains. This forms the basis of the phage typing system [for example, see Wentworth (1963) for an explanation of phage typing of the staphylococci]. Superficially, such apparent host specificity is counterintuitive given the vast number of phages in the biosphere. At an estimated $10^{31}$ particles, phages are the most abundant biological entity on Earth, and outnumber bacteria 10:1 (Hendrix, 2002).

tPresent address: Pathogen Genomics, The Wellcome Trust Sanger Institute, Hinxton, Cambridge CB10 1SA, UK.
It is likely that any surface feature can serve as a phage receptor (Lindberg, 1973). Indeed, some membrane proteins were first identified through their ability to permit phage growth. For example, LamB (the maltose porin) binds phage $\lambda$, and TonA (renamed FhuA) binds phage T1 (see Heller, 1992 for further examples). In our experience, although anecdotal, LPS may be the most frequently used phage receptor in enteric bacteria. Alternative surface macromolecules, e.g. pili in the case of $\Phi C b K$ (Skerker \& Shapiro, 2000), and flagella in the case of phage $\chi$ (Schade et al., 1967), are known to permit phage infection.

Transduction, one of the three mechanisms of horizontal transfer of DNA in bacteria, drives adaptive evolution of bacterial hosts. Given that one model estimates $\sim 10^{14}$ transduction events per year in the Tampa Bay Estuary alone (Jiang \& Paul, 1998), this mechanism is probably a very important source of genetic dissemination. In the laboratory, transduction protocols have been adapted to facilitate transposon mutagenesis, cosmid complementation and facile strain construction (Palva et al., 1981; De Vries et al., 1984), and thus they represent a significant tool for the genetic investigation of bacteria.

The generalized transducing phage described in this study was isolated on an unspeciated member of the genus Serratia: strain ATCC 39006 (Serratia 39006). Subsequent host-range analysis identified an additional host: a strain of Pantoea agglomerans. Both of these strains produce secondary metabolites that have potential biotechnological 
applications, and Serratia 39006 is established as a model organism for the investigation of the regulation of secondary metabolites.

Serratia 39006 produces the red pigment prodigiosin, as well as a carbapenem antibiotic. Prodigiosins, as prodiginines, have a diverse range of biological activities (Williamson et al., 2006), but it is their anti-cancer activity that is currently being investigated in clinical trials (Nguyen et al., 2007). The biosynthesis and regulation of prodigiosin have been studied in some detail (Thomson et al., 2000; Williamson et al., 2005; Slater et al., 2003; Fineran et al., 2005a, b, 2007), and some of this work has been facilitated by the facile construction of double and triple mutant strains using ФOT8.

The strain of $P$. agglomerans, 9Rz4, used in this study was isolated from the rhizosphere, and is reported to have antifungal activity against Rhizoctonia solani, Sclerotinia sclerotiorum and Verticillium dahliae (Berg et al., 2002). Given that these are pathogens of many plants of economic importance, $P$. agglomerans demands further investigation for its potential as a biocontrol agent. The commercial use of bacteria in biocontrol is well established: Agrobacterium radiobacter and Streptomyces lydicus are used as microbial fungicides, under the names Nogall (http://www.bioglobal. com.tr/en/nogall) and Actinovate (http://www.natural industries.com/), respectively.

\section{METHODS}

Bacterial strains, growth and media. Bacterial strains used in this study are listed in Tables 1 and 2. Overnight cultures of all strains were grown in Luria-Bertani broth (LB) $\left(1^{-1}: 10 \mathrm{~g}\right.$ tryptone, $5 \mathrm{~g}$ yeast extract and $5 \mathrm{~g} \mathrm{NaCl}$ ) at $30{ }^{\circ} \mathrm{C}$, except Citrobacter rodentium and Escherichia coli strains, which were grown at $37{ }^{\circ} \mathrm{C}$, and Erwinia strains, which were incubated at $25{ }^{\circ} \mathrm{C}$. Growth on solid medium used LB supplemented with $1.5 \%$ agar (LBA). Minimal medium

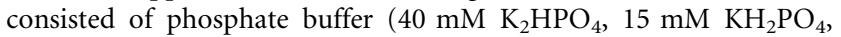
$\mathrm{pH} 7.0), 0.2 \%(\mathrm{w} / \mathrm{v})\left(\mathrm{NH}_{4}\right)_{2} \mathrm{SO}_{4}, 0.2 \%(\mathrm{w} / \mathrm{v})$ sucrose and $0.1 \mathrm{M}$ $\mathrm{MgSO}_{4}$. Where required, kanamycin $(\mathrm{Km})$ and spectinomycin $(\mathrm{Sp})$ were added to a final concentration of $50 \mu \mathrm{g} \mathrm{ml}^{-1}$, tetracycline (Tc) was added to a final concentration of $10 \mu \mathrm{g} \mathrm{ml}^{-1}$ and chloramphenicol $(\mathrm{Cm})$ was added to a final concentration of $25 \mu \mathrm{g} \mathrm{ml}^{-1}$.

Phage isolation, titration and preparation of lysates. Phage were isolated from treated sewage effluent collected from Finham Sewage Treatment Works, Coventry, UK. A $10 \mathrm{ml}$ filter-sterilized sample $(0.2 \mu \mathrm{m}$ filter; Millipore) was added to $10 \mathrm{ml} 2 \times \mathrm{LB}$ and $100 \mu \mathrm{l}$ of an overnight culture of Serratia 39006, and incubated with shaking at $30{ }^{\circ} \mathrm{C}$. After 4 days, $1 \mathrm{ml}$ samples were taken, and centrifuged at $13000 \mathrm{~g}$ for $5 \mathrm{~min}$. The supernatant was removed and $50 \mu \mathrm{l}$ $\mathrm{NaHCO}_{3}$-saturated chloroform was added. Serial dilutions of the supernatant were added to a top lawn of agar seeded with Serratia 39006 , and incubated at $30{ }^{\circ} \mathrm{C}$ overnight. To purify phage, wellseparated plaques were picked, resuspended in $50 \mu \mathrm{l}$ phage buffer [10 mM Tris/ $\mathrm{HCl}, \mathrm{pH} 7.4,10 \mathrm{mM} \mathrm{MgSO}_{4}$ and $0.01 \%(\mathrm{w} / \mathrm{v})$ gelatin], and serial dilutions were plated, as described below.

Phage lysates were produced by taking the agar from the top lawn of confluent lysis, and vortexing it with $4 \mathrm{ml}$ phage buffer and $500 \mu \mathrm{l}$ $\mathrm{NaHCO}_{3}$-saturated chloroform. This was centrifuged at $2219 \mathrm{~g}$ for $20 \mathrm{~min}$ at $4{ }^{\circ} \mathrm{C}$. The supernatant was collected, and $100 \mu \mathrm{NaHCO}_{3^{-}}$ saturated chloroform was added. Phage lysates were stored at $4{ }^{\circ} \mathrm{C}$. Titres were determined after serial dilution.

Host-range analysis. Sensitivity of bacterial strains to phage was tested on agar top lawns of bacteria containing $4 \mathrm{ml} 0.35 \%$ LBA and $200 \mu \mathrm{l}$ of an overnight culture of the test strain. A $10 \mu \mathrm{l}$ volume of a ФOT8 lysate (at $\sim 10^{10}$ p.f.u. $\mathrm{ml}^{-1}$ ) was spotted on the lawn, and plates were incubated overnight at $30{ }^{\circ} \mathrm{C}$, before scoring for lysis.

Electron microscopy. The method for electron microscopy was adapted from the method described by Skerker \& Shapiro (2000). Strain 4SCARA $(100 \mu \mathrm{l})$ and ФOT8 $\left(100 \mu \mathrm{l}\right.$; at $\sim 10^{10}$ p.f.u. $\left.\mathrm{ml}^{-1}\right)$ were mixed, and incubated for $15 \mathrm{~min}$. Samples were fixed with $200 \mu$ fixative (5\% glutaraldehyde in $50 \mathrm{mM}$ cacodylate- $\mathrm{HCl}$ buffer,

Table 1. Bacterial strains and plasmids used in this study

Additional strains used in transduction experiments are described in Table 2.

\begin{tabular}{|c|c|c|}
\hline Strain or plasmid & Genotype & Reference \\
\hline \multicolumn{3}{|l|}{ Strains } \\
\hline Serratia sp. ATCC 39006 & $\begin{array}{l}\text { Note: a lac derivative isolated in this laboratory was used throughout } \\
\text { this study }\end{array}$ & Bycroft et al. (1987) \\
\hline MCR2000 & smaR: : cat derivative of Serratia 39006 & This study \\
\hline 4SCARA & pigX:: mini-Tn5Sm/Sp, carA:: mini-Tn5lacZ1 derivative of Serratia 39006 & Williamson et al. (2008) \\
\hline OT8R 9 & flhC derivative of Serratia 39006 & This study \\
\hline OT8R 11 & flhA derivative of Serratia 39006 & This study \\
\hline POT8R 7 & motA derivative of strain $9 \mathrm{Rz} 4$ & This study \\
\hline $9 \mathrm{Rz} 4$ & P. agglomerans wild-type strain isolated from the rhizosphere & Berg et al. (2002) \\
\hline E. coli $\beta 2163$ & & Demarre et al. (2005) \\
\hline SM10 $\lambda$ pir & & De Lorenzo et al. (1990) \\
\hline \multicolumn{3}{|l|}{ Plasmids } \\
\hline pQE80-L & Cloning vector & Qiagen \\
\hline pflhAE & Serratia 39006 flhAE cloned into pQE80-L & This study \\
\hline pDS1028 & Delivery plasmid for mutagenesis & Smith (2005) \\
\hline pUTmini-Tn5Sm/Sp & Delivery plasmid for mini-Tn $5 \mathrm{Sm} / \mathrm{Sp}$ & De Lorenzo et al. (1990) \\
\hline
\end{tabular}


Table 2. Transduction efficiency within, and between, Serratia 39006 and $P$. agglomerans

\begin{tabular}{|c|c|c|c|c|c|}
\hline Strain & $\begin{array}{c}\text { Transduced resistance } \\
\text { marker }\end{array}$ & $\begin{array}{l}\text { Co-inherited } \\
\text { phenotype }^{\star}\end{array}$ & $\begin{array}{c}\text { Transduction } \\
\text { efficiency }\end{array}$ & m.o.i. & Source \\
\hline \multicolumn{6}{|c|}{ Transduction within Serratia 39006} \\
\hline AX1 & $S p$ & Auxotrophy & $4.9 \times 10^{-4}$ & & This study \\
\hline AX4 & $\mathrm{Sp}$ & Auxotrophy & $2.2 \times 10^{-4}$ & & This study \\
\hline AX11 & $S p$ & Auxotrophy & $1.8 \times 10^{-4}$ & & This study \\
\hline AX13 & $\mathrm{Sp}$ & Auxotrophy & $2.1 \times 10^{-4}$ & & This study \\
\hline $\mathrm{AX} 21$ & $S p$ & Auxotrophy & $1.3 \times 10^{-4}$ & & This study \\
\hline MCP2L & $\mathrm{Km}$ & Pigment production & $3.1 \times 10^{-4}$ & & This study \\
\hline Lac-1 (pTROY9) & $\mathrm{Tc}$ & & $4.0 \times 10^{-6}$ & & This study \\
\hline \multicolumn{6}{|c|}{ Transduction within $P$. agglomerans } \\
\hline White 1 & $\mathrm{Km}$ & Pigment production & $1.4 \times 10^{-4}$ & 0.002 & This study \\
\hline White 2 & $\mathrm{Km}$ & Pigment production & $4.6 \times 10^{-6}$ & 0.05 & This study \\
\hline Aux 1 & $\mathrm{Km}$ & Auxotrophy & $7.4 \times 10^{-5}$ & 0.0002 & This study \\
\hline Aux 1 & $\mathrm{Km}$ & Auxotrophy & $8.3 \times 10^{-5}$ & 0.002 & This study \\
\hline Aux 2 & $\mathrm{Km}$ & Auxotrophy & $7.3 \times 10^{-5}$ & 0.05 & This study \\
\hline $\mathrm{QS}^{-} \mathrm{A}$ & $\mathrm{Km}$ & Lactone production & $5.8 \times 10^{-5}$ & 0.001 & This study \\
\hline $\mathrm{QS}^{-} \mathrm{A}$ & $\mathrm{Km}$ & Lactone production & $6.3 \times 10^{-5}$ & 0.01 & This study \\
\hline \multicolumn{6}{|c|}{ Intergeneric transduction } \\
\hline pMUT13 & $\mathrm{Km}$ & & $3.5 \times 10^{-6}$ & & E. T. Palva \\
\hline
\end{tabular}

${ }^{\star}$ In all cases, there was $100 \%$ co-inheritance of the relevant phenotype and antibiotic resistance.

$\mathrm{pH}$ 7.4) for $10 \mathrm{~min}$ at $25{ }^{\circ} \mathrm{C}$. The cells and phage were collected by centrifugation, washed with $1 \mathrm{ml}$ phage buffer, and resuspended in $100 \mu \mathrm{l}$ phage buffer. Samples were stained with $1 \%$ uranyl acetate, and examined using a Philips CM100 transmission electron microscope.

Transposon mutagenesis, and selection of phage-resistant mutants. Equal volumes of overnight cultures of donor and recipient cells were mixed, and $30 \mu \mathrm{l}$ samples were spotted on non-selective LBA for overnight incubation at $30{ }^{\circ} \mathrm{C}$. The mating patch was scraped into $1 \mathrm{ml} \mathrm{LB}$, and then washed, resuspended in $100 \mu \mathrm{LB}$, and spread on selective agar plates. The recipient strain, donor strain and antibiotic selection used for isolation of Serratia 39006 auxotrophic mutants were MCR2000, SM10 $\lambda$ pir (pUTmini-Tn5Sm/Sp), and Sp and $\mathrm{Cm}$, respectively. Auxotrophic requirements were identified using the plate pool method of Holliday (1956). For phage-resistant mutants, $50 \mu \mathrm{l}$ of the resuspended mating patch was mixed with $200 \mu \mathrm{l}$ phage and mixed into a top lawn of $4 \mathrm{ml} 0.35 \%$ LBA. The recipient strain, donor strain and antibiotic selection used, respectively, were MCA54, BW20767 (pDS1028), Cm (note: minimal medium was used instead of LBA) for Serratia 39006 phage-resistant mutants; and $P$. agglomerans, E. coli $\beta 2163$ (pNRW124), Km for $P$. agglomerans phage-resistant mutants. Diaminopimelic acid was added to all media, at a final concentration of $300 \mu \mathrm{M}$, for growth of $\beta 2163$.

Motility assays. Motility was assayed using tryptone swarm agar [0.3\% (w/v) Bacto agar (Becton Dickinson), $1 \%(\mathrm{w} / \mathrm{v})$ Bacto tryptone (Becton Dickinson) and $0.5 \%(\mathrm{w} / \mathrm{v}) \mathrm{NaCl}$. A $4 \mu \mathrm{l}$ volume of an overnight bacterial culture, diluted to an $\mathrm{OD}_{600}$ of 0.2 , was spotted onto the agar, and incubated overnight at $25{ }^{\circ} \mathrm{C}$. The diameter of the halo was measured after $16 \mathrm{~h}$.

Cloning of flhAE, and mapping transposon mutants. flhAE was amplified from Serratia 39006 using primers oTE64 (ATGAGCTCTAAATAAATAAAAAGAGGAGATATGACTGATGGCTAATCTGG) and oTE65 (TAAAGCTTGAAGTAGACGTAGCACTTTGTC). Following digestion with SacI and HindIII, and purification, the fragment was cloned into pQE80 digested with the same enzymes, using standard molecular techniques (Sambrook et al., 1989). The genes disrupted in phage-resistant mutants were defined using the random prime PCR protocol described by Fineran et al. (2005b).

Adsorption assays. Adsorption of ФOT8 to Serratia 39006 was carried out by using protocols described by Petty et al. (2006) for phage infecting Serratia marcescens Db11.

Generalized transduction. Phage lysates were prepared, as described above, on bacterial strains carrying the desired mutation or plasmid. Overnight cultures $(10 \mathrm{ml})$ of the recipient strain were centrifuged at $6000 \mathrm{~g}$ for $10 \mathrm{~min}$, and the cells were resuspended in $1 \mathrm{ml} \mathrm{LB}$. The frequency of spontaneous resistance to antibiotics was determined by spreading $100 \mu \mathrm{l}$ of the cell suspension on LBA containing the relevant antibiotic. An appropriate volume of the transducing lysate was added to the remaining cells to give the desired m.o.i., and it was then mixed, and incubated for $1 \mathrm{~h}$ at $30^{\circ} \mathrm{C}$. A $100 \mu \mathrm{l}$ volume was spread on agar plates containing the relevant antibiotic to select for the acquisition of the antibiotic-resistance gene. Transductants were then screened for the relevant co-inherited phenotype (auxotrophy, pigmentation or lactone production). A $100 \mu$ volume of the phage lysate was also spread on non-selective agar plates to confirm sterility.

Test for lysogeny. ФОТ8 was tested for lysogeny by using the methods described by Petty et al. (2006).

Analysis of phage proteins. A high-titre phage lysate was treated with DNase I $\left(1 \mu \mathrm{g} \mathrm{ml}^{-1}\right)$ and RNase A $\left(1 \mu \mathrm{g} \mathrm{ml}{ }^{-1}\right)$ at room temperature for $30 \mathrm{~min}$. $\mathrm{NaCl}$ was added to a final concentration of $1 \mathrm{M}$, and this was followed by incubation on ice for $1 \mathrm{~h}$, and centrifugation at $11000 \mathrm{~g}$ for $10 \mathrm{~min}$ at $4{ }^{\circ} \mathrm{C}$. PEG 8000 (Sigma) was added to a final concentration of $10 \%(\mathrm{w} / \mathrm{v})$, followed by incubation on ice for $1 \mathrm{~h}$. The precipitated phage preparation was centrifuged at $11000 \mathrm{~g}$ for $10 \mathrm{~min}$ at $4{ }^{\circ} \mathrm{C}$, and the supernatant was discarded. The pellet was resuspended in $2 \mathrm{ml}$ phage buffer. A $2 \mathrm{ml}$ volume of 
$\mathrm{NaHCO}_{3}$-treated chloroform was added, and the mixture was vortexed, and centrifuged at $3000 \mathrm{~g}$ for $15 \mathrm{~min}$ at $4{ }^{\circ} \mathrm{C}$. $\mathrm{CsCl}$ $\left(0.75 \mathrm{~g} \mathrm{ml}^{-1}\right)$ was dissolved in the supernatant, and then the supernatant was centrifuged at $35000 \mathrm{~g}$ for $24 \mathrm{~h}$ at $4{ }^{\circ} \mathrm{C}$, using an SW50.1 rotor. The ultracentrifuge tube was pierced with a hypodermic syringe, and the white band of phage particles was removed. It was then transferred to dialysis tubing, and dialysed in 51 $50 \mathrm{mM}$ Tris/ $\mathrm{HCl}$ (pH 8.0) overnight.

Phage protein samples $(40 \mu \mathrm{l})$ were mixed with $10 \mu \mathrm{l} 5 \times$ loading buffer [50 mM Tris/HCl (pH 6.8), $50 \%$ glycerol, $1 \%$ bromophenol blue, $5 \mathrm{mM}$ EDTA], boiled for $4 \mathrm{~min}$, and loaded onto an SDS-PAGE gel (3.3\% stacking gel; $13-23 \%$ gradient resolving gel).

$\mathrm{N}$-terminal sequencing of proteins was carried out by the Protein and Nucleic Acid Chemistry Facility in the Department of Biochemistry, University of Cambridge, Cambridge, UK.

Purification of phage DNA, and restriction digests. Phage DNA was purified from lysates made by substituting agarose for agar in the top lawns. Restriction digest reactions contained $500 \mathrm{ng}$ DNA, and were done, as directed by the manufacturer, using $2 \mu$ enzyme (New England Biolabs). Following a $16 \mathrm{~h}$ incubation at $37^{\circ} \mathrm{C}$, samples were run on a $1 \%$ agarose gel.

\section{RESULTS AND DISCUSSION}

\section{The host range of ФОТ8}

ФOT8 was isolated by enrichment using treated sewage effluent. Clear plaques with a diameter of 1-2 mm were seen in $0.3 \%$ agar top lawns.

To investigate the host range of ФОТ8, a collection of 21 clinical and environmental S. marcescens isolates (described in detail by Harris et al., 2004) were tested for phage sensitivity by spot test. Also tested were the following enteric strains studied in this laboratory: Erwinia carotovora subsp. atroseptica SCRI 1043, Erwinia carotovora subsp. carotovora MH1000, Erwinia carotovora subsp. carotovora MS102, Yersinia enterolitica, E. coli TG1, E. coli DH1, C. rodentium ICC169 and S. marcescens Db11. None of the strains was found to be phage-sensitive (A. Harris, personal communication; I. Foulds, personal communication). Subsequently, 29 strains isolated from the rhizosphere by Berg et al. (2002) were also tested for ФОТ8 sensitivity. One strain, 9Rz4, was susceptible to phage infection, as determined by using spot tests. Strain 9Rz4 was identified as $P$. agglomerans by fatty acid methyl ester analysis (Berg et al., 2002) and 16S rDNA sequencing (data not shown), and is referred to as $P$. agglomerans hereafter. Phage sensitivity of $P$. agglomerans was confirmed by a full titration to isolated plaques with $\Phi O T 8$. While plaques were very small and often difficult to see, the efficiency of plaquing on $P$. agglomerans was the same as that on Serratia 39006, and this suggested that there was no hostcontrolled restriction (data not shown).

\section{ФОТ8 is flagellum-dependent}

All Serratia 39006 mutants that were spontaneously resistant to ФOT8 were non-motile. This suggested that the receptor for ФOT8 was the flagellum. Indeed, both Serratia 39006 and P. agglomerans are motile (data not shown). We tried to show flagellum dependence via transmission electron microscopy, as described in Methods. However, unambiguous evidence of direct binding of the phage to the flagellum was not obtained, even when using the hyperflagellated Serratia 39006 strain 4SCARA (Table 1). The electron micrographs (Fig. 1) showed that ФOT8 is a member of the Siphoviridae family. ФOT8 had an icosahedral head, with a diameter of $97 \mathrm{~nm}$. Head size correlates with genome size (Leffers \& Rao, 1996). Therefore, by comparison with phages of a similar size (e.g. ФIF3; Petty et al., 2006), the results suggest a genome size of approximately $250 \mathrm{~kb}$ for ФOT8. The tail was flexible, and there was no evidence of it being contractile. A base plate was attached to the distal end of the tail.

To identify the receptor of $\Phi О T 8$, phage-resistant, transposon-insertion derivatives of Serratia 39006 and $P$. agglomerans mutant banks were selected. Transposoninsertion sites were determined by sequencing the transposon-chromosome boundaries (Table 1). Many structural components of the flagellum are represented in this list, though the impact of most mutations is likely to be more dramatic than they appear, due to polar effects on polycistronic gene clusters. In contrast, a functional MotA, the gene for which is mutated in strain POT8R 7,
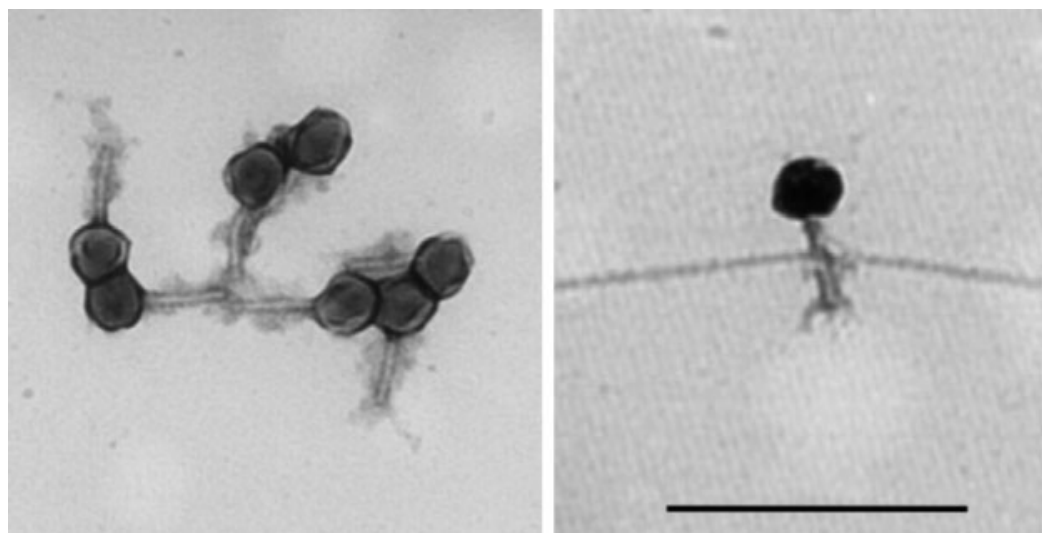

Fig. 1. Transmission electron micrographs of ФOT8 stained with uranyl acetate. Left: the phages were identified as Siphovidae because of their flexible, non-contractile tails. Right: a base plate and tail fibres are evident; a flagellum runs horizontally across the micrograph. Bar, $500 \mathrm{~nm}$. 
is not necessary for flagella biosynthesis in Salmonella typhimurium (Enomoto, 1966), and the Erwinia carotovora subsp. carotovora motA mutant remained peritrichously flagellated (Hossain et al., 2005). motA mutants have been termed 'paralysed' because, despite the presence of flagella, they are non-motile. The fact that the motA mutant is phage-resistant in $P$. agglomerans may demonstrate the need for a functional flagellum or a chemotactic response for phage infection. This is reminiscent of phage $\chi$, which is a flagellatropic coliphage. Phage $\chi$ first binds to the flagellum, but motility is important for the translocation of the phage along the filament to its ultimate receptor at the cell surface (Schade et al., 1967).

The flhA mutant, which is deficient in flagellum export (Ghelardi et al., 2002), had the dual phenotype of phage resistance and non-motility, as predicted. This mutant was chosen for genetic complementation tests because, by comparison with gene organization in other genomes, the gene is predicted not to be part of a large operon. The Serratia 39006 flhAE locus has been sequenced (GenBank accession no. FN396602). The phage sensitivity and motility phenotypes were complemented in trans using a plasmid construct that overexpressed flhAE. Phage sensitivity of the complemented strain was fully restored: mean (SD) phage titres (p.f.u. $\mathrm{ml}^{-1}$ ) were $2.5 \times 10^{9}\left(4.6 \times 10^{8}\right)$ for Serratia 39006 (pQE80) (wild-type), 0 (0) for OT8R 11 (pQE80) (flhA mutant), and $3.7 \times 10^{9}\left(1.3 \times 10^{9}\right)$ for OT8R 11 (pflhAE) (complemented strain). Motility was restored to $\sim 50 \%$ of the wild-type level: mean (SD) halo diameters $(\mathrm{mm})$ were 38 (1) were for Serratia 39006 (pQE80), 5 (0) for OT8R 11 (pQE80), and 17 (2) for OT8R 11 (pflhAE). The discrepancy in the halo diameter values for the wildtype strain and the complemented strain may be due to copy number effects leading to aberrant regulation of the flhAE genes.

If ФОТ8 depends on the flagellum for adsorption to the bacterium, adsorption to a non-flagellated strain should be abolished, as has been shown for the Erwinia flagellatropic phage, ФAT1 (Evans et al., 2009). As shown in Fig. 2, this was also true for ФOT8. In this case, OT8R 19 was chosen as the non-flagellated strain, as $f l h C$ (part of the flagella 'master' operon) is mutated in this strain.

\section{ФОТ8 is a generalized transducing phage}

In a crude screen for novel generalized transducing phages, TOT8 was tested and found to be capable of mediating transduction of auxotrophic markers between Serratia 39006 strains. In order to optimize the experimental conditions, the effect of m.o.i. on transduction efficiency (defined as the number of transductants per p.f.u.) was determined. For the following m.o.i., the number of transductants and transduction efficiency, respectively, were obtained. m.o.i 0.001: $4900,4.9 \times 10^{-4}$; m.o.i. 0.01: $15000,1.5 \times 10^{-4}$; m.o.i. $0.1: 60000,6.0 \times 10^{-5}$. The results showed that as more phage were used, the absolute number of transductant colonies recovered also increased.

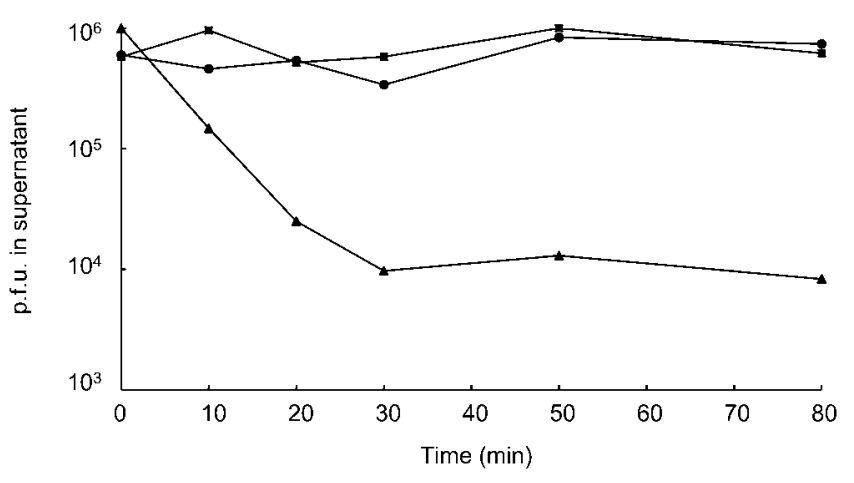

Fig. 2. Adsorption of ФOT8 to Serratia 39006 derivatives was measured by determining the levels of phage present in culture supernatants. There was no adsorption of phage to the $\mathrm{flhC}$ mutant OT8R 19 ( $\boldsymbol{\square})$. In contrast, the parental strain MCA54 (A) adsorbed phage rapidly, with $97 \%$ of the phage being removed from the culture supernatant by $30 \mathrm{~min}$. $\bullet$, Negative control (LB only).

However, a drop in transduction efficiency was observed, probably due to superinfection killing of transductants. The transduction efficiency mediated by ФOT8 was very high compared with that of many other transducing phages. For example, the recently described transducing phages CCR1 and ФIF3 have optimal transduction efficiencies of $10^{-8}$ and $10^{-6}$ transductants per p.f.u., respectively (Petty et al., 2006, 2007). The large genome size of ФOT8 may contribute to the high efficiency of transduction, since it permits the packaging of large amounts of bacterial DNA in transducing particles.

Transduction efficiencies were determined for various markers in Serratia 39006 and P. agglomerans, and they demonstrated the generalized nature of the transduction (Table 2). The efficiencies recorded for $P$. agglomerans were approximately an order of magnitude lower than those obtained for Serratia 39006; this may reflect inherent variation in the transduction of different markers rather than an underlying difference in phage replication within the two strains. However, marked differences are sometimes seen with broad-host-range transducing phages. For example, three transducing phages that each infect both Streptococcus thermophilus and Lactococcus lactis displayed transduction efficiencies that were four orders of magnitude lower in L. lactis compared with those in $S$. thermophilus, and this was explained by the weak absorption of the phage to L. lactis (Ammann et al., 2008). The lower transduction efficiencies seen in $P$. agglomerans compared with Serratia 39006 may be a consequence of less avid adsorption of ФOT8 to $P$. agglomerans.

Transduction of a plasmid from P. agglomerans to Serratia 39006 was also demonstrated. A slightly lower transduction efficiency was seen for plasmid transduction compared 
with that for transduction of chromosomal markers; this is consistent with results obtained for other transducing phages (Petty et al., 2007). In the plasmid-transduction experiment conducted here, an antibiotic-resistance gene was moved between the two bacterial genera. Phages are well known for their ability to mediate horizontal acquisition of DNA by bacteria, and this most strikingly manifests itself as lysogenic conversion (Canchaya et al., 2004). However, there are wider ecological implications, and incorporation of new DNA into a bacterial host may have more subtle effects than the acquisition of toxin genes. The results presented here underscore similar findings in Gram-positive strains that have been published recently (Ammann et al., 2008; Chen \& Novick, 2009).

\section{ФОТ8 is virulent}

While Serratia 39006 colonies were recovered after ФOT8 exposure (that is, they were either lysogens immune to superinfection, or they were phage-resistant), phage particles were not detected in the culture supernatants following overnight growth. Therefore, the colonies were probably spontaneous phage-resistant mutants rather than superinfection-resistant lysogens. Plaques obtained with ФOT8 were always found to be clear. Thus, there was no evidence that $\Phi \mathrm{OT} 8$ is a temperate phage.

\section{Analysis of phage proteins and DNA}

To analyse the structural proteome of ФOT8, a purifed phage preparation was run on an SDS-PAGE gel. In total, 13 bands were seen (Fig. 3). The two most prominent bands, with sizes of approximately 24 and $31 \mathrm{kDa}$, were excised and submitted for $\mathrm{N}$-terminal sequencing. However, the sequences obtained (SXDLSLSRFX for the $24 \mathrm{kDa}$ protein, and SLGETLAQEI for the $31 \mathrm{kDa}$ protein) were not similar to any sequences in the BLAST database (http://blast.ncbi.nlm.nih.gov/Blast.cgi). This result emphasizes the fact that comparatively little sequence data have been obtained for phages (Lima-Mendez et al., 2007).

We attempted to produce restriction enzyme digests of purified phage genomic DNA. However, ФOT8 genomic DNA was resistant to cleavage by restriction enzymes BamHI, EcoRI, EcoRV and HindIII, even after incubation for $16 \mathrm{~h}$ (data not shown). Inhibition of bacterial restriction endonucleases by phage proteins has been observed, notably in phage P1 infections when DarA and DarB are co-injected with the phage DNA into the bacterial cell (Iida et al., 1987). To exclude the possibility that inhibitors were contaminating the DNA preparations, phage $\lambda$ DNA was mixed with ФOT8 DNA prior to incubation with HindIII. Complete digestion of $\lambda$ DNA was seen, discounting the possibility that an inhibitor was present (data not shown). Apart from inhibition, a number of anti-restriction strategies are known to be employed by phage; these strategies include elimination of recognition sequences from the genome, and incorporation of

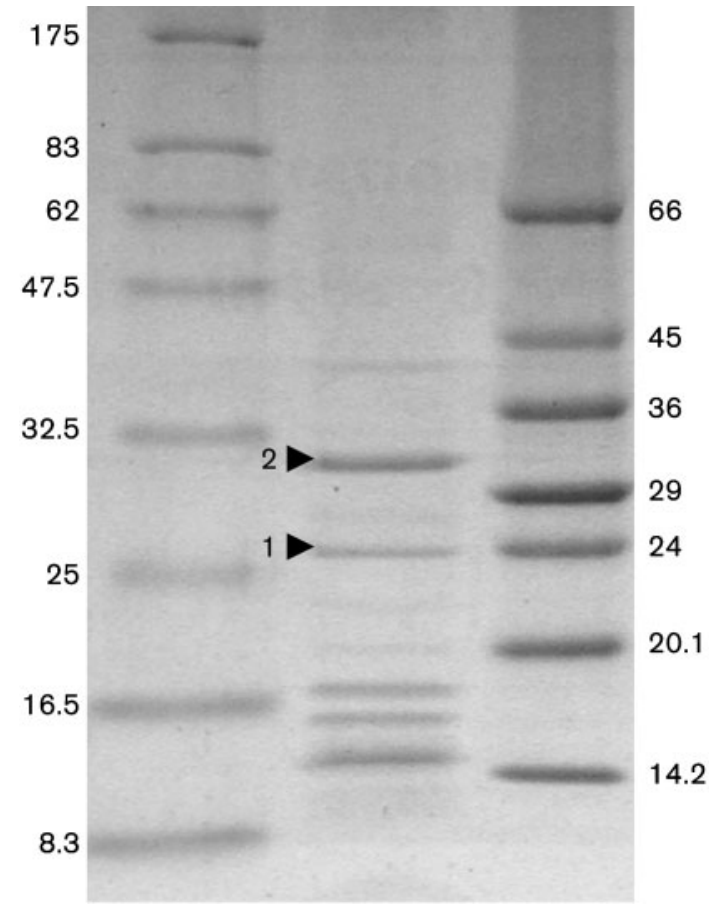

Fig. 3. A purified phage preparation was analysed by SDS-PAGE (middle lane). Molecular mass markers $(\mathrm{kDa})$ are shown in the outside lanes. The two dominant bands (arrows) were N-terminally sequenced (see text).

modified bases (Tock \& Dryden, 2005). However, it seems unlikely that the genome has no recognition sites for four different endonucleases, especially given the proposed large genome size. Thus, it seems most plausible that the genome of ФOT8 contains chemically modified, atypical nucleotide bases; perhaps this is a feature that contributes to the broad host range of this phage.

\section{Conclusions}

The finding that ФOT8 is flagellum-dependent was surprising because the flagellum is not often used in this way. Indeed, Petty et al. found that $92 \%$ of newly isolated Serratia phages use LPS as their receptor (Petty et al., 2006), and this is consistent with results obtained for phages isolated on other enteric species, in this laboratory (Petty et al., 2007; data not shown).

Notwithstanding the well-known broad-host-range phages such as Mu and P1 (Harshey, 1988; Yarmolinsky \& Sternberg, 1988), phage host range is popularly thought to be narrow; this view is enshrined in, and strengthened by, the phage-typing system for classifying bacteria (reviewed by Pitt \& Gaston, 1995). Despite a 1998 study specifically assessing the prevalence of broad-host-range phages (Jensen et al., 1998), and recent examples of such phages in Gram-positive genera (Ammann et al., 2008; Chen \& Novick, 2009), the consensus remains that phage 
infection tends to be species and strain specific. However, other examples of broad-host-range phages have been reported (for example, see Gill et al., 2003), and such a stringent model of phage-bacterium interactions fails to explain the abundance of phages in the environment. Neither of the bacterial strains used in this study has been genomically sequenced, and the P. agglomerans strain has not been characterized in detail. Therefore it is difficult to quantify how similar the strains are. However, they are both Gram-negative enterobacteria that were isolated from the soil: a salt marsh in the USA, in the case of Serratia 39006; and the rhizosphere of oilseed rape in Germany, in the case of $P$. agglomerans.

Identification of phage susceptibility is usually based on plaque formation; this is a demanding test. However, we have shown here that plaques are not always easily observed even when a bacterial host permits viral replication: the plaques may be intermittently too small to see under the conditions employed. Since the lack of a positive result in crude phage spot tests does not necessarily indicate complete phage resistance, a more reliable method to identify alternative bacterial hosts might result in the reclassification of many so-called narrow-hostrange phages.

Furthermore, in terms of horizontal dispersal of DNA, lysis of a bacterium is not required for transduction to occur. For example, coliphage $\mathrm{P} 1$ is able to adsorb to, and inject DNA into, Myxococcus xanthus cells, thus forming transductants, but viral replication is not seen within this species (Kaiser \& Dworkin, 1975). Taken together, this means that interspecies and intergeneric transduction is likely to be more prevalent than we currently believe, particularly since phagemediated acquisition of DNA is already reckoned to occur on a very large scale (Jiang \& Paul, 1998).

\section{ACKNOWLEDGEMENTS}

This work was funded by the BBSRC. T.J.E. held a Collaborative Award in Science and Engineering with Leatherhead Food International. We thank G. Hatfull for useful discussions, and $\mathrm{K}$. Smalla for supplying the rhizosphere strains.

\section{REFERENCES}

Ammann, A., Neve, H., Geis, A. \& Heller, K. J. (2008). Plasmid transfer via transduction from Streptococcus thermophilus to Lactococcus lactis. J Bacteriol 190, 3083-3087.

Berg, G., Roskot, N., Steidle, A., Eberl, L., Zock, A. \& Smalla, K. (2002). Plant-dependent genotypic and phenotypic diversity of antagonistic rhizobacteria isolated from different Verticillium host plants. Appl Environ Microbiol 68, 3328-3338.

Bycroft, B. W., Maslen, C., Box, S. J., Brown, A. \& Tyler, J. W. (1987). The isolation and characterisation of $(3 \mathrm{R}, 5 \mathrm{R})$ - and $(3 \mathrm{~S}, 5 \mathrm{R})$-carbapenem-3-carboxylic acid from Serratia and Erwinia species and their putative biosynthetic role. J Chem Soc Chem Commun 21, 1623-1625.

Canchaya, C., Fournous, G. \& Brüssow, H. (2004). The impact of prophages on bacterial chromosomes. Mol Microbiol 53, 9-18.
Chen, J. \& Novick, R. P. (2009). Phage-mediated intergeneric transfer of toxin genes. Science 323, 139-141.

De Lorenzo, V., Herrero, M., Jakubzik, U. \& Timmis, K. N. (1990). Mini-Tn 5 transposon derivatives for insertion mutagenesis, promoter probing, and chromosomal insertion of cloned DNA in Gramnegative eubacteria. J Bacteriol 172, 6568-6572.

Demarre, G., Guerout, A.-M., Matsumoto-Mashimo, C., RoweMagnus, D. A., Marliere, P. \& Mazel, D. (2005). A new family of mobilizable suicide plasmids based on broad host range R388 plasmid (IncW) and RP4 plasmid (IncP $\alpha$ ) conjugative machineries and their cognate Escherichia coli host strains. Res Microbiol 156, 245-255.

De Vries, G. E., Raymond, C. K. \& Ludwig, R. A. (1984). Extension of bacteriophage $\lambda$ host range: selection, cloning, and characterization of a constitutive $\lambda$ receptor gene. Proc Natl Acad Sci U S A 81, 6080-6084.

Enomoto, M. (1966). Genetic studies of paralyzed mutants in Salmonella. I. Genetic fine structure of the mot loci in Salmonella typhimurium. Genetics 54, 715-726.

Evans, T. J., Trauner, A., Komitopoulou, E. \& Salmond, G. P. C. (2009). Exploitation of a new flagellatropic phage of Erwinia for positive selection of bacterial mutants attenuated in plant virulence: towards phage therapy. J Appl Microbiol, doi:10.1111/j.1365-2672.2009.04462.x

Fineran, P. C., Everson, L., Slater, H. \& Salmond, G. P. C. (2005a). A GntR family transcriptional regulator (PigT) controls gluconatemediated repression and defines a new, independent pathway for regulation of the tripyrrole antibiotic, prodigiosin, in Serratia. Microbiology 151, 3833-3845.

Fineran, P. C., Slater, H., Everson, L., Hughes, K. \& Salmond, G. P. C. (2005b). Biosynthesis of tripyrrole and $\beta$-lactam secondary metabolites in Serratia: integration of quorum sensing with multiple new regulatory components in the control of prodigiosin and carbapenem antibiotic production. Mol Microbiol 56, 1495-1517.

Fineran, P. C., Williamson, N. R., Lilley, K. S. \& Salmond, G. P. (2007). Virulence and prodigiosin antibiotic biosynthesis in Serratia are regulated pleiotropically by the GGDEF/EAL domain protein, PigX. J Bacteriol 189, 7653-7662.

Ghelardi, E., Celandroni, F., Salvetti, S., Beecher, D. J., Gominet, M., Lereclus, D., Wong, A. C. L. \& Senesi, S. (2002). Requirement of $f l h A$ for swarming differentiation, flagellin export, and secretion of virulence-associated proteins in Bacillus thuringiensis. J Bacteriol 184, 6424-6433.

Gill, J. J., Svircev, A. M., Smith, R. \& Castle, A. J. (2003). Bacteriophages of Erwinia amylovora. Appl Environ Microbiol 69, 2133-2138.

Harris, A. K., Williamson, N. R., Slater, H., Cox, A., Abbasi, S., Foulds, I., Simonsen, H. T., Leeper, F. J. \& Salmond, G. P. C. (2004). The Serratia gene cluster encoding biosynthesis of the red antibiotic, prodigiosin, shows species- and strain-dependent genome context variation. Microbiology 150, 3547-3560.

Harshey, R. M. (1988). The Bacteriophages, vol. 1, pp. 193-234. Edited by R. Calendar. New York: Plenum.

Heller, K. J. (1992). Molecular interaction between bacteriophages and the Gram-negative cell envelope. Arch Microbiol 158, 235-248.

Hendrix, R. W. (2002). Bacteriophages: evolution of the majority. Theor Popul Biol 61, 471-480.

Holliday, R. (1956). A new method for the identification of biochemical mutants of micro-organisms. Nature 178, 987-988.

Hossain, M. M., Shibata, S., Aizawa, S.-I. \& Tsuyumu, S. (2005). Motility is an important determinant for pathogenesis of Erwinia carotovora subsp. carotovora. Physiol Mol Plant Pathol 66, 134-143.

lida, S., Streif, M. B., Bickle, T. A. \& Werner, A. (1987). Two DNA antirestriction systems of bacteriophages P1, darA, and darB: characterization of darA $^{-}$phages. Virology 157, 156-166. 
Jensen, E. C., Schrader, H. S., Rieland, B., Thompson, T. L., Lee, K. W., Nickerson, K. W. \& Kokjohn, T. A. (1998). Prevalence of broad-hostrange lytic bacteriophages of Sphaerotilus natans, Escherichia coli, and Pseudomonas aeruginosa. Appl Environ Microbiol 64, 575-580.

Jiang, S. C. \& Paul, J. H. (1998). Gene transfer by transduction in the marine environment. Appl Environ Microbiol 64, 2780-2787.

Kaiser, D. \& Dworkin, M. (1975). Gene transfer to a myxobacterium by Escherichia coli phage P1. Science 187, 653-654.

Leffers, G. \& Rao, V. B. (1996). A discontinuous headful packaging model for packaging less than headful length DNA molecules by bacteriophage T4. J Mol Biol 258, 839-850.

Lima-Mendez, G., Toussaint, A. \& Leplae, R. (2007). Analysis of the phage sequence space: the benefit of structured information. Virology 365, 241-249.

Lindberg, A. A. (1973). Bacteriophage receptors. Annu Rev Microbiol 27, 205-241.

Nguyen, M., Marcellus, R. C., Roulston, A., Watson, M., Serfass, L., Madiraju, S. R. M., Goulet, D., Viallet, J., Bélec, L. \& other authors (2007). Small molecule obatoclax (GX15-070) antagonizes MCL-1 and overcomes MCL-1-mediated resistance to apoptosis. Proc Natl Acad Sci U S A 104, 19512-19517.

Palva, E. T., Liljeström, P. \& Harayama, S. (1981). Cosmid cloning and transposon mutagenesis in Salmonella typhimurium using phage $\lambda$ vehicles. Mol Gen Genet 181, 153-157.

Petty, N. K., Foulds, I. F., Pradel, E., Ewbank, J. J. \& Salmond, G. P. C. (2006). A generalized transducing phage ( $\Phi I F 3)$ for the genomically sequenced Serratia marcescens strain Db11: a tool for functional genomics of an opportunistic human pathogen. Microbiology 152, 1701-1708.

Petty, N. K., Toribio, A. L., Goulding, D., Foulds, I., Thomson, N., Dougan, G. \& Salmond, G. P. C. (2007). A generalized transducing phage for the muring pathogen Citrobacter rodentium. Microbiology 153, 2984-2988.

Pitt, T. L. \& Gaston, M. A. (1995). Bacteriophage typing. Methods Mol Biol 46, 15-26.

Sambrook, J., Fritsch, E. F. \& Maniatis, T. (1989). Molecular Cloning: a Laboratory Manual, 2nd edn. Cold Spring Harbr, NY: Cold Spring Harbor Laboratory.
Schade, S. Z., Adler, J. \& Ris, H. (1967). How bacteriophage $\chi$ attacks motile bacteria. J Virol 1, 599-609.

Skerker, J. M. \& Shapiro, L. (2000). Identification and cell cycle control of a novel pilus system in Caulobacter crescentus. EMBO J 19, 3223-3234.

Slater, H., Crow, M., Everson, L. \& Salmond, G. P. C. (2003). Phosphate availability regulates biosynthesis of two antibiotics, prodigiosin and carbapenem, in Serratia via both quorum-sensingdependent and -independent pathways. Mol Microbiol 47, 303-320.

Smith, D. S. (2005). Development of a positive selection strategy to investigate the regulation of quorum sensing in Erwinia. $\mathrm{PhD}$ thesis, University of Cambridge, UK.

Thomson, N. R., Crow, M. A., McGowan, S. J., Cox, A. \& Salmond, G. P. (2000). Biosynthesis of carbapenem and prodigiosin pigment in Serratia is under quorum sensing control. Mol Microbiol 36, 539-556.

Tock, M. R. \& Dryden, D. T. (2005). The biology of restriction and anti-restriction. Curr Opin Microbiol 8, 466-472.

Wentworth, B. B. (1963). Bacteriophage typing of the staphylococci. Bacteriol Rev 27, 253-272.

Williamson, N. R., Simonsen, H. T., Ahmed, R. A., Goldet, G., Slater, H., Woodley, L., Leeper, F. J. \& Salmond, G. P. C. (2005). Biosynthesis of the red antibiotic, prodigiosin, in Serratia: identification of a novel 2methyl-3-n-amyl-pyrrole (MAP) assembly pathway, definition of the terminal condensing enzyme, and implications for undecylprodigiosin biosynthesis in Streptomyces. Mol Microbiol 56, 971-989.

Williamson, N. R., Fineran, P. C., Leeper, F. J. \& Salmond, G. P. C. (2006). The biosynthesis and regulation of bacterial prodiginines. Nat Rev Microbiol 4, 887-899.

Williamson, N. R., Fineran, P. C., Ogawa, W., Woodley, L. R. \& Salmond, G. P. C. (2008). Integrated regulation involving quorum sensing, a two-component system, a GGDEF/EAL domain protein and a post-transcriptional regulator controls swarming and RhlAdependent surfactant biosynthesis in Serratia. Environ Microbiol 10, 1202-1217.

Yarmolinsky, M. B. \& Sternberg, N. (1988). The Bacteriophages, vol. 1, pp. 291-438. Edited by R. Calendar. New York: Plenum.

Edited by: J. Moir 